研究

\title{
チタン繊維のパルス通電焼結
}

小林 慶三, 尾崎 公洋, 西尾 敏幸, 多田 周二, 中山 博行, 三上 祐史

(独) 産業技術総合研究所サステナブルマテリアル研究部門，† 463-8560 名古屋市守山区下志段味穴が洞 2266-98.

\section{Pulsed Current Sintering of Titanium Fiber}

\author{
Keizo Kobayashi, Kimihiro Ozaki, Toshiyuki Nishio, Syuji Tada, Hiroyuki Nakayama and Yushi Mikami \\ National Institute of Advanced Industrial Science and Technology, Material Research Institute for Sustainable Development, \\ 2266-98 Anagahora, Shimoshidami, Moriyama-ku, Nagoya 463-8560, Japan.
}

Received August 17, 2009

\section{SYNOPSIS}

Porous titanium compacts were prepared by a pulsed current sintering of titanium fiber under a low pressure. The punch fixed on the electrode enabled the fabrication of the porous material with any thickness. When a nonconductive die was used for the pulsed current sintering, pulsed current was passed to titanium fiber directly. Therefore the each titanium fiber of $100 \mu \mathrm{m}$ diameter was joined by applying $0-800 \mathrm{~A}$ pulse current for five seconds. When the frequency of the pulsed current was higher, the compact was sufficiently heated, and the junction of the titanium fiber became strong. In these experimental conditions, the porous titanium compact having porosity from $40 \%$ to $60 \%$ were formed stably.

The junction of the titanium fiber occurred in the early stage of the pulsed current sintering and became stronger by the latter heating. Even if the obtained porous titanium compact heated in the air, most of the joints between the titanium fibers did not come off.

KEY WORDS

pulsed current sintering, titanium fiber, porous material, porosity, frequency

\section{1 緒 言}

パルス通電焼結は, 導電性のある型に粉末を充填し, パル ス状の電流を流しながら加圧して焼結する技術1)である. 原 理的にはホットプレスに近い焼結技術であるが, 焼結する対 象粉末が金属のように導電性を有する粉末である場合には, 粉末にも電気が流れるために少し焼結メカニズムが異なって くる ${ }^{2)}$ もと考えられる，粉末に電気が流れると，粉末の接 触部分では電気抵抗が大きくなるため, 大きなジュール加熱 が発生して粉末どうしの焼結が短時間に生じ, 緻密化を促進 するものと考えられる. パルス通電焼結では導電性を有する 型として，一般的には黒鉛が利用され，型に流れる電流の ジュール加熱により焼結体全体の温度を比較的容易に制御す ることができる．また，一般のヒーターを用いた加熱に比べ て加熱空間が小さいため, 省エネルギーの焼結技術と考える こともできる.

パルス通電焼結において, 粉末ではなく金属繊維を用いる と, 繊維の接触部分に生じるジュール加熱により接触部分を
接合して多孔質成形体を作製することができる.これまでに 非導電性の型に銅繊維を充填し，低加圧下でのパルス通電焼 結により任意の気孔率を有する多孔質成形体を作製できるこ

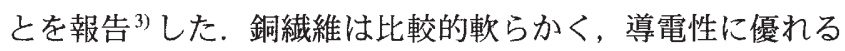
ため, 低い加圧力下で高いパルス電流を高い周波数で短時間 付与することで多孔質成形体に加工することができた．

本研究では, 本プロセスをチタン繊維に適用して多孔質成 形体を作製することを目的とした. チタン緎維は銅繊維に比 べて剛性が高く, 焼結雾囲気による炭化や酸化の問題があり, 多孔質体への成形条件は銅繊維の場合とは異なってくるもの と考えられる. そこで, 多孔質成形体の気孔率やパルス条件 を変化させて，チタン多孔質成形体の作製を試みた。

\section{2 試料及び実験方法}

出発原料として Fig. 1 にSEM写真を示す断面形状が $80 \mu \mathrm{m} \times$ $40 \mu \mathrm{m}$ 程度の矩形であるチタン繊維を用い，パルス通電焼結 による多孔質成形体を作製した. チタン緎維はチタン箔を 


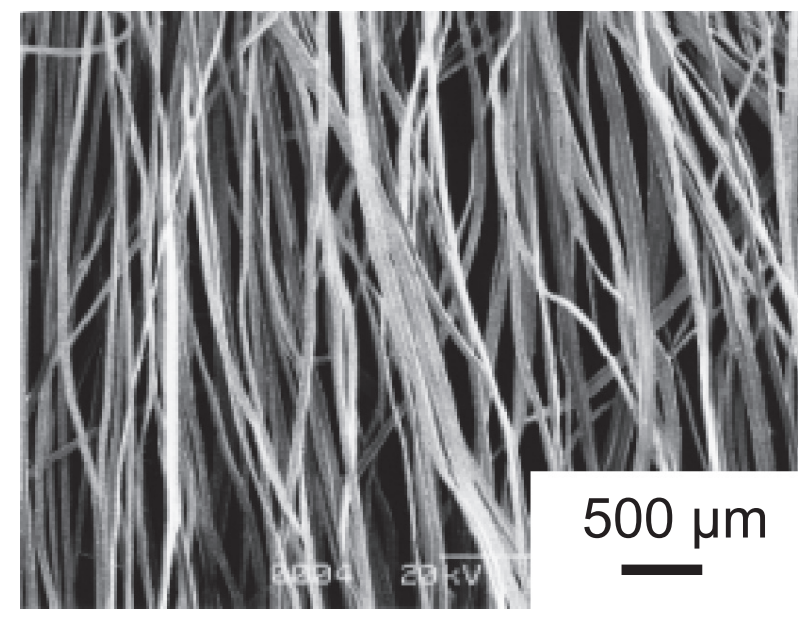

Fig.1 SEM images of titanium fiber.

ロール状にして機械加工により作製した緎維であるため, そ の断面は矩形になっているものである. チタン繊維を内径 10 $\mathrm{mm}$, 外径 $15 \mathrm{~mm}$ で高さ $30 \mathrm{~mm}$ のパイレックス製パイプに充 填し，黒鉛製のパンチを用いてパルス通電焼結に供した。パ ルス通電焼結には加圧力を小さくできる機械式の加圧機構を 有し, パルス状の電流を印加するためのインバー夕式電源を 有しているPLASMAN (エス・エス・アロイ製)を用いた。な お,パルス通電焼結は $10 \mathrm{~Pa}$ 程度の真空雾囲気にて行い, 繊 維表面の酸化を防止した.

通電条件は, パルス電流のピーク電流値, ボトム電流値, 周 波数, 電流の ON/OFF比 (デューティ比と記す), 通電時間を 変化させることができるが, 予備実験の結果からボトム電流 を $0 \mathrm{~A}$, ピーク電流を $800 \mathrm{~A}$, デューティ比を $50 \%$ として, 通 電時間と周波数による焼結性の変化について検討した.また. 成形体の気孔率による焼結性の違いを検討するため，パイ レックス製パイプに充填するチタン繊維の重量を変化させて, 気孔率が $70 \%, 60 \%, 50 \%$ の成形体を作製した.

任意の厚み (本実験では $2 \mathrm{~mm}$ )の成形体を得るため, パル 又通電焼結装置はFig.2 (a)のように改造を行った。本装置は 上部電極を機械的な駆動機構により制御して加圧する構造で あるため, 上部パンチを電極に固定した。上部パンチは黒鈶 製であり, Fig.2(b)のように電極と接する部分をステンレス 鋼製治具で固定した. パンチの位置は機械的に駆動する部分 にて測定できるため, 繊維をはさまずに上下パンチどうしが 接触した位置をゼロ点とした. 所定の重量のチタン繊維をパ イレックス製パイプに充填した後, 上部パンチを下降させて 目的の成形体厚みの位置で停止させた。一般のパルス通電焼 結では，加圧力を一定とした条件で焼結が行われるが，本実 験では上部パンチの位置を固定することで成形を行った.す なわち, 繊維の変形に伴って加圧力は上昇するが, 目的の気 孔率が得られる成形体厚みまで加圧してパンチ位置を固定し た. なお, 通電により繊維間の接合が生じるため加圧力は減 少するが, 本実験条件であれば放電や電気的な断線を生じる
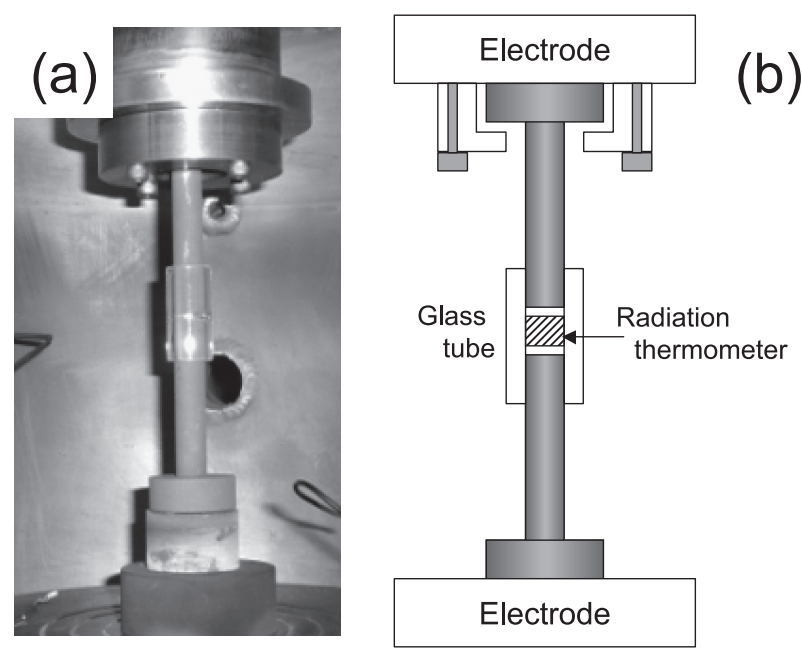

Fig.2 The apparatus for the pulsed current sintering under a low pressure. (a) appearance and (b) schematic drawing.

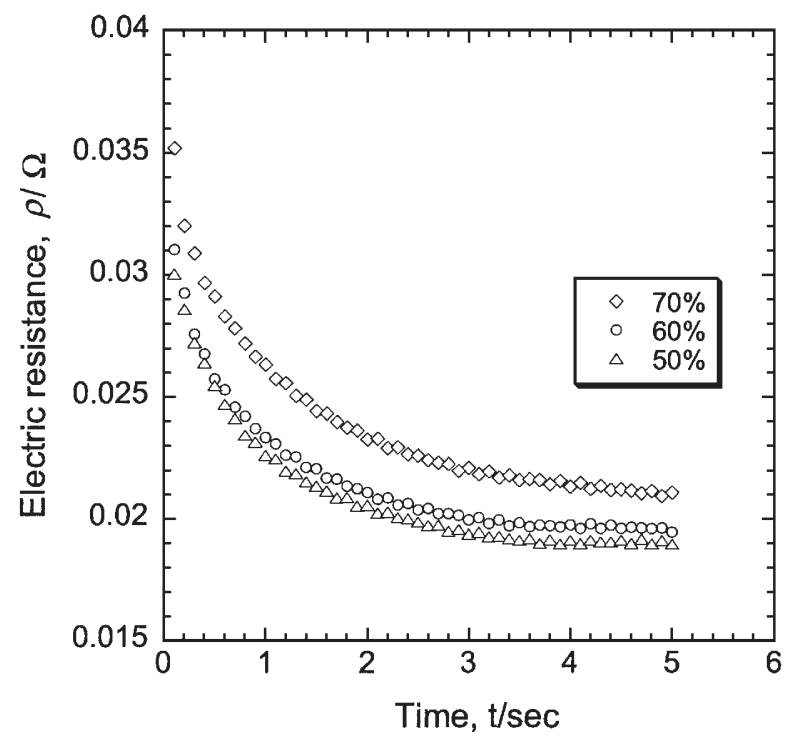

Fig.3 Electric resistance of porous titanium compact with a various porosity plotted against current-carrying time.

\section{ことなく通電を行うことができた.}

パルス電流の通電時の電流, 電圧, 加圧力を測定するとと もに, 得られた成形体における繊維の状態をSEMにて観察し $た$.

\section{3 実験結果および考察}

3.1 気孔率およびパルス電流条件による通電特性の変化 充填するチタン繊維の重量を変えて, 気孔率を変化させた 場合のパルス電流通電時間に伴う電気抵抗の変化をFig.3に示 す. ボトム電流 $0 \mathrm{~A}$, ピーク電流 $800 \mathrm{~A}$, デューティ比 $50 \%$ の パルス電流を周波数 $100 \mathrm{~Hz}$ にて 5 秒間通電して測定を行っ た. 電気抵抗はパルス電流の平均電流值と電圧值を実測し, 
それらから計算した系全体 (本装置の電気が流れる回路全体) の值であり,チタン繊維のみの電気抵抗を示すものではない. すなわち, 電源から電極までの電気抵抗や電極部の抵抗. 電 極とパンチの接触抵抗などの電気抵抗も含まれた値として計 算している.ただし，チタン繊維に起因する電気抵抗以外は ほぼ一定であり, Fig.3における各曲線の違いはチタン繊維の 充填割合，すなわち気孔率に起因するものと考えられる. 気 孔率が70\%の場合にはチタン繊維の割合が少ないため, 初期 の電気抵抗は高くなっているが, 通電時間に伴いチ夕ン繊維 間の接合が生じて電気抵抗が低下している. その後, 通電時 間が 4 秒以上になるとほぼ一定の電気抵抗となっており，本 実験条件における接合が終了しているものと考えられる。一 方, 気孔率の小さな $60 \%$ や $50 \%$ の試料では，初期の電気抵 抗は少し小さく, $70 \%$ の試料より早い時間で電気抵抗が一定 值に到達している. また， $60 \%$ と $50 \%$ という気孔率の差異に よる電気抵抗の変化はわずかであった，これは，パイプの中 に充填したチタン繊維の割合がある程度以上になると繊維の 接触部の数があまり増加しないため, 接触部の接合が同程度 の通電時間で完了することを意味するものと考えられる.さ らに気孔率を低下させると繊維は点接触から面接触に変わり, 初期の電気抵抗が小さくなるものと予想されるが, 気孔率を $40 \%$ より小さくして目的の $2 \mathrm{~mm}$ 厚みの成形体を得るには初 期加圧力が大きくなり，パイレックス製パイプでは対応がで きなかった.なお, 通電時の温度分布を目視にて観察したが, 通電初期には繊維の接触部が高温になっているようであるが, 通電の後半では黒鉛製のパンチの方が成形体より高い温度を 示していた，得られた成形体はいずれの気孔率においても， 繊維どうしの接合が見られ，パイプから取り出しても形状の 変化は認められなかった。

気孔率を変えることにより, 初期の加圧力および通電に伴 う加圧力の変化が観察された。 そこで, パルス通電時の加圧

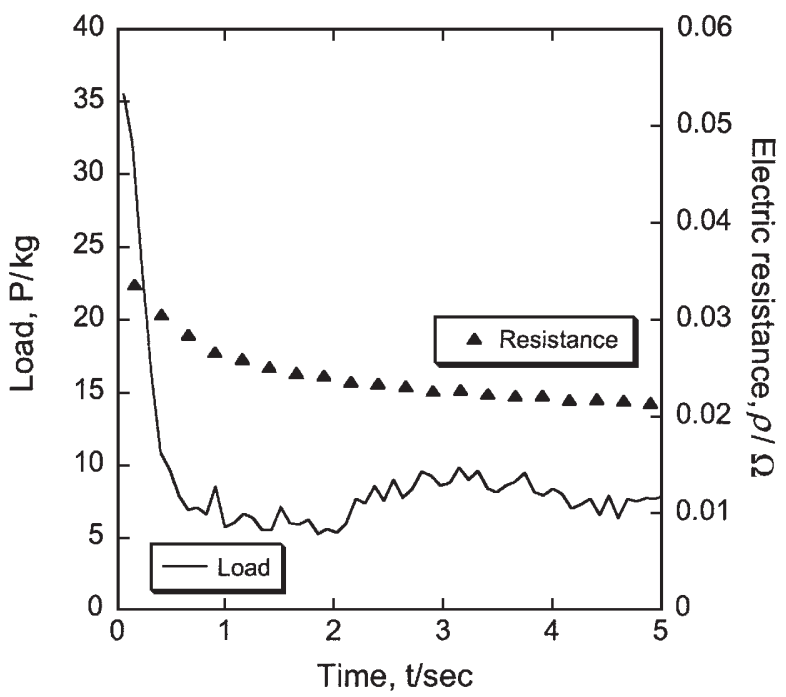

Fig.4 Load and electric resistance of porous titanium compact plotted against current-carrying time.
力変化を調べた. 通電時の加圧力の変化をより明確に調べる ため,パイレックス製パイプが破壊されない限界の気孔率 $40 \%$ にてパルス電流を印加した。パルス電流はボトム電流 $0 \mathrm{~A}$, ピーク電流 $800 \mathrm{~A}$, デューティ比 $50 \%$, 周波数 $100 \mathrm{~Hz}$ にて 5 秒 間の通電を行った。通電時間に伴う電気抵抗と加圧力 (荷重) の変化を Fig.4に示す. 気孔率を $40 \%$ としても先の気孔率 $60 \%$ や50\%の成形体と電気抵抗の違いは認められなかった. 通電 に伴う加圧力は通電初期( 1 秒以内)に大きく低下しており, 繊 維間の接合が進行したものと考えられる.その後はほとんど 加圧力に変化はなく, $10 \mathrm{~kg}$ 以下の低い加圧力となっている. 本装置では $10 \mathrm{~kg}$ 以下の加圧力については厳密な测定ができ ていないため, 絶対值を議論することはできないが, 通電が 行える程度の加圧力は維持できているものと考えられる.す なわち, 繊維どうしの接合が通電初期に生じても電極から離 れるような繊維の焼結は生じていないものと考えられる.

パルス通電の周波数の影響を調べるため, ボトム電流 $0 \mathrm{~A}$, ピーク電流 $800 \mathrm{~A}$, デューティ比 $50 \%$ で気孔率 $60 \%$ の成形体 に対して周波数を変えた通電を 5 秒間行った. 通電時間に伴 う試料温度の変化を赤外線放射温度計により測定した結果を Fig.5に示す. 本実験の放射温度計では 873 K以下の測定がで きないため, その温度以下の場合はすべて $873 \mathrm{~K}$ と表示され ている. 周波数が $50 \mathrm{~Hz}$ と低い場合には, 加熱と冷却が比較 的ゆっくりと繰り返されるため，通電時間中に試料温度が $873 \mathrm{~K}$ を超えることはなかった。しかし，周波数が $100 \mathrm{~Hz}$ 以上 では加熱と冷却の周期が速いため, 試料は 5 秒間で $1000 \mathrm{~K}$ を 超える温度まで上昇した. 周波数が高い場合にはパルス波形 の制御が矩形波から多少ずれてしまうが, 繊維試料を加熱す る必要がある場合には高い周波数を付与することが有効であ るものと考えられる.なお, チタン繊維の接合状態は $50 \mathrm{~Hz}$ はやや弱く，型から取り出すとわずかに膨らんだが， $100 \mathrm{~Hz}$

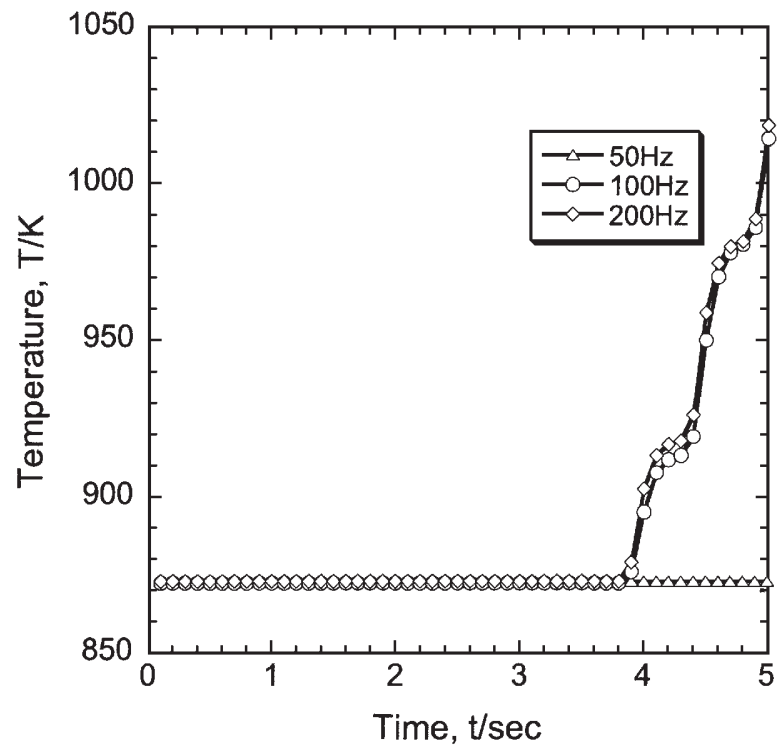

Fig.5 Temperature of porous titanium compact measured by radiation thermometer plotted against current-carrying time. 
や $200 \mathrm{~Hz}$ の試料ではしっかりと接合されており, 型から取り 出しても成形体の厚みの変化は認められなかった. チタン緎 維の接合では繊維を加熱した方が強い接合状態になることが わかった。 また, 得られた成形体は目的の厚みより小さく なっておらず, 本実験条件では高い周波数でも加熱による成 形体の焼結はほとんど進行しなかったものと考えられる. 通 電時の加熱は先述したように, 通電初期には䋐維の接触部分 で高温部が発生しているが, 通電後期には黒鉿製パンチ部の 温度が最も高くなっていた. このため, 通電を停止した後も パンチからの伝熱により成形体温度は上昇するが，これによ る焼結の進行も認められなかった。

ボトム電流 $0 \mathrm{~A}$, ピーク電流 $800 \mathrm{~A}$, デューティ比 $50 \%$, 周波 数 $100 \mathrm{~Hz}$ のパルス電流を5 秒間印加して作製した気孔率 $60 \%$ の成形体をFig.6に示す.パイレックス製パイプ内に密着する 形でチタン繊維が成形されており，もともとまっすぐであっ たチタン繊維は複雑に曲がって成形体を構成していることが わかる. 㵶維間の接合により織維どうしは固定されているた め, 繊維が外れることはなかった. ただ，5秒間という短時 間の通電では, 瀻維 1 本ごとの形状 (断面が矩形) は Fig. 1 と 同じであり，繊維をパイレックス製パイプに押し込んだ形で 繊維が点で接合された状態であった。

3.2 パルス通電焼結を用いた 2 段階加熱による多孔体の作製

チタン䋐維をパルス通電により多孔質成形する際には, 通 電初期に繊維間での接合が生じ, その後の加熱で接合部が強 化されることがわかった. しかし，多孔質体の用途によって は䄉維表面を滑らかにしたり, 接合部を太くしてより強固に する必要が生じる. その対策としては, 纎維の接合後に多孔

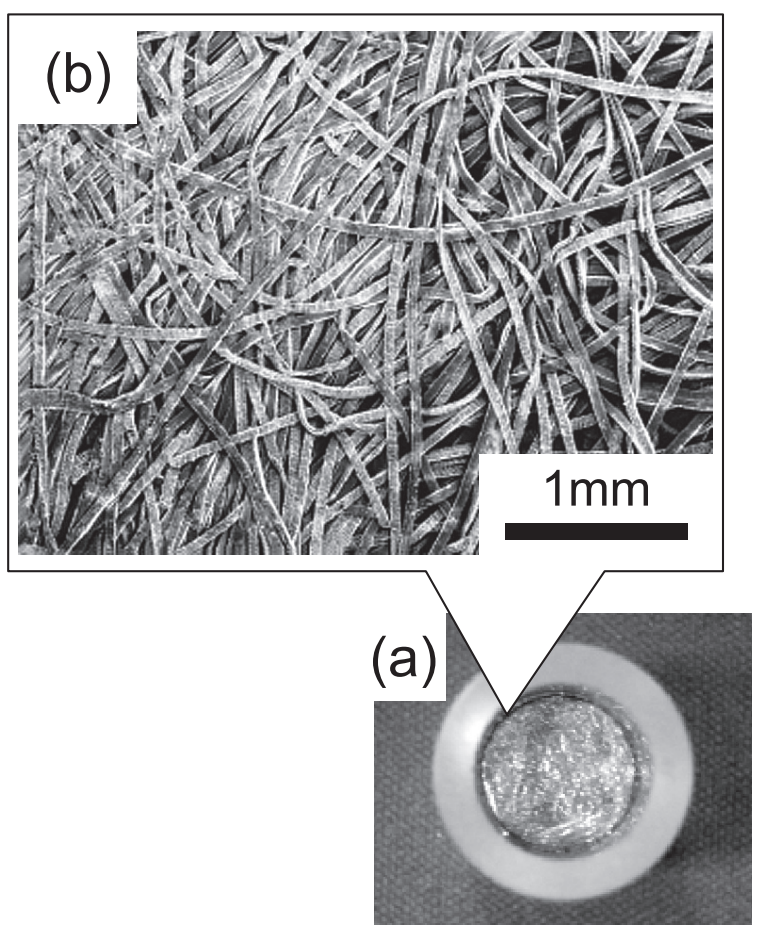

Fig.6 The apparatus (a) and SEM image (b) for the porous titanium compact.
質体を加熱することが好ましいものと考えられる. そこで, ボトム電流 $0 \mathrm{~A}$, ピーク電流 $800 \mathrm{~A}$, デューティ比 $50 \%$, 周波数 $100 \mathrm{~Hz}$ のパルス電流を 5 秒間通電した後, さらにボトム電流 $0 \mathrm{~A}$, ピーク電流 $600 \mathrm{~A}$, デューティ比 $50 \%$, 周波数 $100 \mathrm{~Hz}$ の パルス電流を 10 秒間印加して気孔率 $60 \%$ の成形体を作製し た. 先述したようにパルス通電の後半では黒鉛製パンチ部分 が高温となり，その伝熱によって成形体が加熱される現象が 見受けられる. そのため測温部である成形体の温度制御が難 しくなり, 繊維の焼結が急速に進むことがある.ピーク電流 值を下げることで, 黒欽製パンチの温度と成形体の温度がほ ぼ一定になるようにして加熱を行った. 通電時間に伴う電気 抵抗と成形体温度の変化をFig.7に示す.ピーク電流を制御す ることで黒鉛パンチからの伝熱を抑えながら,成形体を必要 以上に加熱することなく通電を行うことができた. また, 電 気抵抗は通電初期に大きな変化があるもののその後はあまり 大きな変化は観察されなかった.このようにして作製した多 孔質成形体のチタン繊維はFig.8 (b)のように繊維表面が凸凹 になっており，繊維の矩形断面もくずれていた. Fig.6の成形 体では Fig.8 (a)のように瀻維表面の変化はほとんど認められ ないことから, 繊維接合後の加熱によりチタン表面の細かい 凹凸が一部軟化・溶融して大きな凸凹になったものと考えら れる.なお，本実験では黒鉿製パンチを使用しているため酸 化に伴う繊維表面の色変化は観察されなかったが, これ以上 加熱するとパンチとチタン織維は反応した. さらに, 繊維表 面を滑らかにするには, 繊維を高温で長時間処理する必要が あり,パルス条件を最適化してチタン繊維の表面改質を行わ なければならない。2 段階の加熱により作製したチタン緎維 多孔質体は織維の接合も強固になっているものと考えられ, 大気中で加熱して青色を呈する薄い酸化被膜を形成しても, 接合部における繊維の剥離は認められず, 多孔質成形体の形 状が維持されることが確認できた.

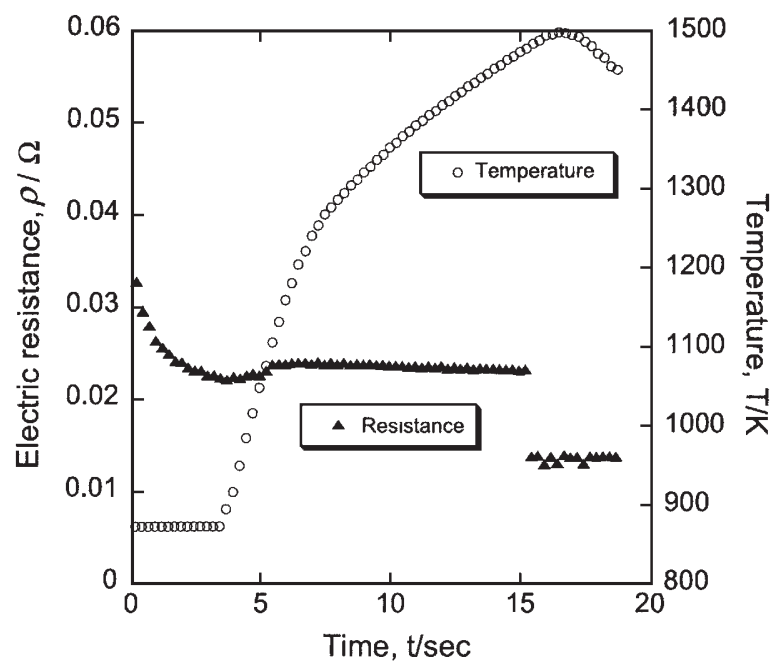

Fig.7 Electric resistance and temperature of the porous titanium compact with two steps heating plotted against currentcarrying time. 

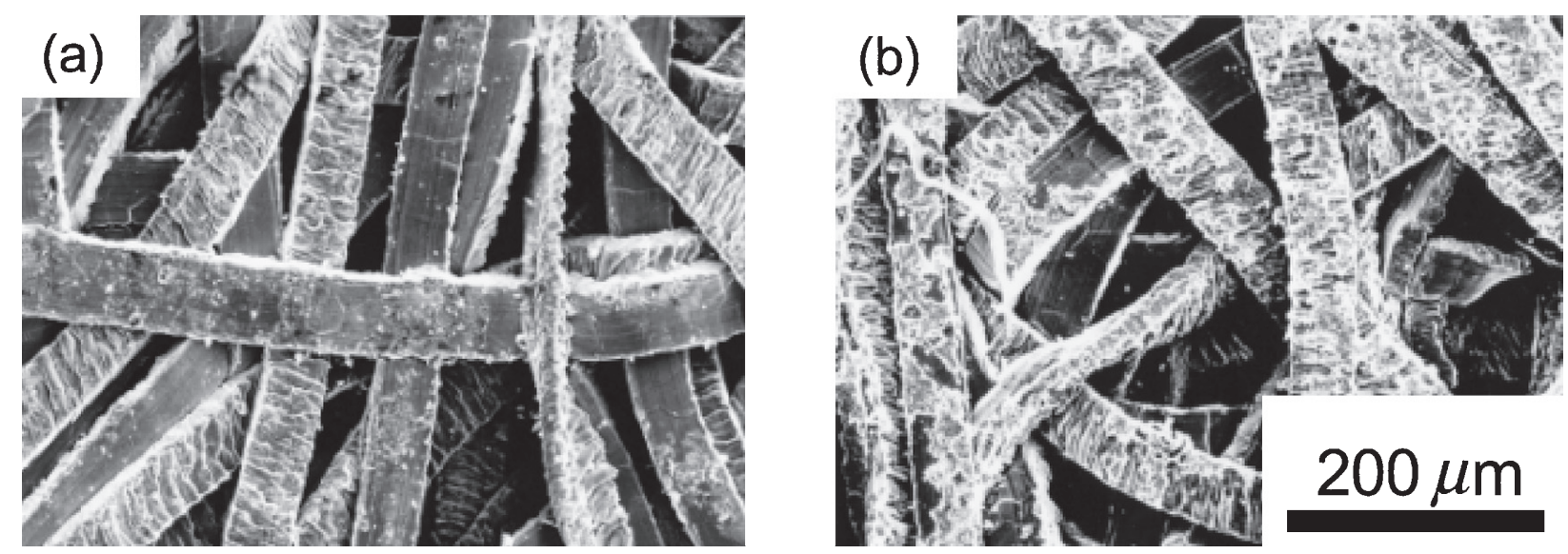

Fig.8 SEM image of porous titanium compacts. (a) one step heating and (b) two steps heating.

\section{4 ま と め}

$80 \mu \mathrm{m} \times 40 \mu \mathrm{m}$ 程度の矩形断面を有するチタン繊維にパルス 電流を印加することで, 多孔質体に成形することを試みた。 また, 多孔質成形時の気孔率やパルス電流の周波数などの影 響について検討した。 その結果，下記の結論が得られた。

(1) チタン繊維をボトム電流 $0 \mathrm{~A}$, ピーク電流 $800 \mathrm{~A}$, デュー ティ比 $50 \%$ のパルス電流により多孔質成形体を作製する ことができる、繊維間の接合は通電初期に生じる.

(2) 本実験条件では, 気孔率40-60\%の多孔質成形体において 大きな差異が認められない.また, 周波数は成形体の加熱 に影響を与え，100-200 Hzであれば同程度の加熱が行え る.

(3) 成形体における繊維の表面改質や接合強度の向上には繊 維間の接合後の加熱が有効である. 接合後に加熱を行う
ことで, 大気中で酸化被膜が形成しても接合部が剥離し ない強固な接合を実現できる.

\section{文 献}

1) M. Tokita: "Trends in Advanced SPS Spark Plasma Sintering Systems and Technology", J. Soc. Powder Technology, Jpn., 30(1993)790-804.

2) K. Ozaki, K. Kobayashi, T. Nishio, A. Matsumoto, and A. Sugiyama: "Sintering Phenomena on Initial Stage in Pulsed Current Sintering", J. Jpn. Soc. Powder Powder Metallurgy, 47 (2000) 293-297.

3) K. Kobayashi: "Functional Materials Prepared by Pulsed Current Sintering Control the Use of Pressure", J. Jpn. Soc. Powder Powder Metallurgy, 54(2007)570-575. 